\title{
Identification of Poisonous Plants and Their Toxics Effects on Livestock in Horo Buluk District, Horo Guduru Wollega Zone, Oromia Regional State, Western Ethiopia
}

\author{
Diriba Gurmesa and Debela Abdeta* \\ Wollega University, School of Veterinary Medicine, Ethiopia \\ *Corresponding author: Debela Abdeta, School of Veterinary Medicine, Wollega University, Ethiopia
}

\begin{tabular}{|c|c|}
\hline ARTICLE INFO & ABSTRACT \\
\hline 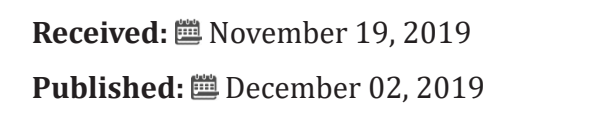 & $\begin{array}{l}\text { Poisonous plant is one of the causes of livestock health problems all over the world } \\
\text { and brings significant economic loss. Therefore, a cross sectional study was concluded } \\
\text { in and around Horo Buluk district North Horo Guduru Wolega Zone of Oromia Regional }\end{array}$ \\
\hline $\begin{array}{l}\text { Citation: Diriba Gurmesa, Debela Abde- } \\
\text { ta. Identification of Poisonous Plants and } \\
\text { Their Toxics Effects on Livestock in Horo } \\
\text { Buluk District, Horo Guduru Wollega Zone, } \\
\text { Oromia Regional State, Western Ethio- } \\
\text { pia. Biomed J Sci \& Tech Res 23(3)-2019. } \\
\text { BJSTR. MS.ID.003897. } \\
\text { Keywords: Botanical frequency; Ethiopia; } \\
\text { livestock; Poisonous plants; Questionnaire }\end{array}$ & $\begin{array}{l}\text { identifying poisonous plant and their toxic effect in the study area. In order to put the } \\
\text { objective into practice, structured questionnaires were developed and } 130 \text { individuals } \\
\text { basis. At the end of the survey, it was found that } 102(78.5 \%) \text { of livestock owners and } \\
10(100 \%) \text { of animal health practitioner complained the presence of plant poisoning } \\
\text { on livestock's in the study area. Similarly, } 33 \text { plants were identified as having poisoning } \\
\text { effect on livestock, among which Trifolium Hybridium, snowdina polystarchia, Plantago } \\
\text { Laceolata, Urtica doca solanium, guizotia scabra and had the highest botanical frequency. } \\
\text { According to the result of survey, agricultural expansion, draught, soil erosion and } \\
\text { overgrazing predispose the livestock's to plant poisoning. In the same way, almost all of } \\
\text { the livestock's were managed by extensive type of production system which allows them } \\
\text { to browse poisonous perennial herbs on identified. On the other hand, the livestock's } \\
\text { were poisoned by leaves and other parts of the identified poisonous plants through } \\
\text { ingestion or contract. In conclusion, from the current study, high number of poisonous } \\
\text { plant was obtained in the area. Hence, the livestock health in the area is at high risk } \\
\text { of exposure to these toxic plants and therefore the government should intervene to } \\
\text { create awareness among the community about the effects of these plants and for further } \\
\text { photochemical and toxicological studies and possibly pharmacological activity. }\end{array}$ \\
\hline
\end{tabular}

\section{Introduction}

Plants add a touch of color and fragrance to our daily lives. They also inject an element of anger in our lives and they cannot move to escape their predators. So, all plants have other means of protecting themselves from the herbivores. Some plants have physical such as thorns. But others contain some toxic. Chemical defenses of plants against consumption by herbivores are determined by non-nutrient compounds such as fiber, lignin, cellulose, toxicants or essential oils and other volatile substances. Some volatile substances are overtly toxic others are merely unpleasant [1].
Plant poisoning is due to either accidental ingestion of material eaten along with grass or willful consumption of poisonous plants when pasture is dry while most poisonous plants remain green all the year round. It is also more likely to occur in animals which have been moved from one part of country to another. New importations are unfamiliar with the strange ingestion of their fresh surrounding. Acclimatization in herbivores animals induces a sense of discrimination between edible and non-edible parts [2]. 
Even though many of the medical substances produced by plants [3], some of them have been reported as toxic [4,5]. Plants may cause toxic effects or even death as a result of accidental exposure by skin contact/absorption, eye exposure and inhalation or accidental ingestion of the plant parts (seed, fruit, root, etc) while owner usually does not even suspect their toxic nature [6,7]. Plants affect animals in many ways although symptoms and lesions differ depending on the amount of the plant consumed. The common symptoms however include chronic illness debilitation, decreased weight gain, abortion, abdominal discomfort, salivation, congenital defects, photosensitization and sudden death can occur without the presentation of clinical signs [8].

Currently and rapidly diagnosing a plant poisoning is often extremely difficult. In many cases initial clinical signs are nonspecific (such as diarrhea) and post-mortem lesions may be absent. However, diagnosis of plant poisoning of livestock depends on the history, clinical syndrome observed, post-mortem lesions, evidence that plants have been grazed, and remains of toxic plants in the gastrointestinal tract. In addition, specialized veterinary toxicology laboratories may provide testing for plant toxins and should be consulted. Thus, the best way to support a diagnosis of a plant poisoning is to confirm the presence of a toxic plant in the animal's environment, and to confirm that the plant has been ingested [9].

Awareness of poisonous plants growing in a certain geographical region and their associated clinical signs are instrumental in making a diagnosis and initiate treatment [10]. It is important to establish an accurate diagnosis in order to provide adequate treatment to affected animals, carefully and accurately assess the potential for the transfer of toxins into edible products and prevent further exposures. Most importantly, recognition of poisonous plants in hay or forage may help prevent plant poisonings in animals [11]. In Ethiopia, to this date, most of the available information about poisonous plants is case reports. Thus, it is virgin (neglected) area for interested researchers to fill available gaps regarding paucity of information on the effects of poisonous plants on livestock. Therefore, the objective of this study is: To identify different poisonous plants and their toxic effects on livestock in and around the Oda Buluk District area.

\section{Materials and Methods}

\section{Study Area}

The study was conducted from September 2017 to December 2017 in and around Horo Buluk district, northern Horo Guduru Wolega Zone of Oromia regional state, western Ethiopia. The district is located at $322 \mathrm{~km}$ West of Addis Ababa. It is lies between 37005 '05'- 37007 '45”'East and 9033 '00'-'9035'25”North longitude and on the altitude of 2503 meter above sea level. The mean annual rain fall is $1264 \mathrm{~mm}$, the rain period ranges from April to October. It has a warm humid climate with mean minimum and average temperature of 15.70c (NMSA, 2003). The farming system at the area is crop livestock mixed type. The number of livestock population of the area was, cattle in head (61901), sheep (10112), goat (1100), horse (3795), mule (1054) and donkey (8668) poultry(30749) (CSA, 2008).

\section{Study Population}

The target study populations were voluntary animal owners and animal health practitioners. A total of 120 animal owners and 10 animal health practitioners were interviewed by employing close approaches to collect important data relevant to the study.

\section{Study Design and Sampling Methods}

A cross sectional study was used to interview voluntary animal owners and animal health practitioners. For this study, structured questionnaire was design to collect information related to plant poisoning on livestock in the study area. Questionnaire survey was carried out on the selected individuals by interviewing voluntary animal owners and animal health practitioners. Livestock owners and animal health professionals were randomly selected for the interview. The district was purposefully selected by taking into consideration of distance from the zone and occurrence of a variety of plant vegetation cover in the area different and plant poisoning.

\section{Study Methodology}

The study was conducted through questionnaire surveys designed for livestock owners and animal health professionals. A total of 130 individuals were interviewed from the district by applying face to face approach. The structured questionnaire was used to collect information related to toxic plants to livestock and its associated risk factors such as agricultural expansion, drought, over grazing and soil erosion. The plants were collected with their local name from surrounding forests and other sites where the plant is found with the interview individuals.

\section{Data Management and Analysis}

Suspected poisonous plants to livestock were collected in the area through structured questionnaire and according to the respective respondents the data were stored in the Microsoft Excel spread sheet 2010. Before the analysis of the coded data, it was filtered. Finally, it was analyzed and presented using tables. Lastly by applying descriptive statistics, frequencies and percentage were calculated.

\section{Results}

In this study, a total of 130 individuals were interviewed, of which 120 individuals were livestock owners and 10 individuals were animal health practitioners by employing structured questionnaire. Out of interviewed interviewee, 102 (85\%) individuals complained the presence of poisonous plants in the study area where as 18 (15\%) individuals had no information about the presence of these plants in the study area. Similarly, all of interviewed animal health practitioners $10(100 \%)$ informed the presence of these toxic plants (Table 1). During the present study, a total of 33 plants were identified which have poisonous effects on 
livestock by interviewed individuals. In all interviewed individual extensive type of management is practiced.

Among these plants Trifolium hybridium (20.8\%), Snowdina polystarchia (12.5\%), Plantago Laceolata (10\%), Urtica doca solanium (7.5\%) Guizotia scabra (5.8\%) were the most frequently complained toxic plants (Table 2). According to the result of current study, livestock's were mainly poisoned through contact and/ or ingestion of leaves (51.1\%) and other parts of the poisonous plants (stem, seed and fruit) which account for 34.5\%. On the other hand, livestock's were predisposed to these toxic plants due to agricultural expansion (29.5\%), drought (22.3\%), soil erosion $(8.6 \%)$ and overgrazing (3.6\%) (Table 1$)$.

Table 1: Summary of number respondents on poisonous plants in the study area

\begin{tabular}{|c|c|c|c|}
\hline \multirow{2}{*}{ Group interviewed } & \multirow{2}{*}{ Number interviewed } & \multicolumn{2}{|c|}{ Number of information } \\
\cline { 3 - 4 } & & Have information about poisonous plant & Have no information about poisonous plant \\
\hline Livestock owners & 120 & $102(85 \%)$ & $18(15 \%)$ \\
\hline Animal health practitioners & 10 & $10(100 \%)$ & 0 \\
\hline Total & 130 & $112(86 \%)$ & $18(14 \%)$ \\
\hline
\end{tabular}

Table 2: Summary of the identified poisonous plants according to their botanical and local (Afan Oromo) name, poisonous parts, susceptible species and harmful effects.

\begin{tabular}{|c|c|c|c|c|c|}
\hline Botanic name & Local (Oromic) name & Botanic frequency & $\begin{array}{l}\text { Poisonous parts } \\
\text { (s) }\end{array}$ & $\begin{array}{c}\text { Susceptible species } \\
\text { of animal }\end{array}$ & $\begin{array}{l}\text { Harmful effects of toxic } \\
\text { plant }\end{array}$ \\
\hline Nicotina tabaccum & Tamboo & 2 & Leaf & All animals & $\begin{array}{l}\text { Abortion, birth defects, } \\
\text { staggering weakness }\end{array}$ \\
\hline Hordium vulgare & Garbuu & 2 & Leaf, stem & All animals & $\begin{array}{l}\text { Oral irritation and abs- } \\
\text { cessation }\end{array}$ \\
\hline Bambusa vulgaris & Leemmana & 1 & Leaf & Bovine, Caprine, Ovine & $\begin{array}{l}\text { Parasites of the tongue, } \\
\text { depression, ataxia and in } \\
\text { coordination }\end{array}$ \\
\hline $\begin{array}{c}\text { Arisaema } \\
\text { eunaephyllum }\end{array}$ & $\begin{array}{c}\text { Boqqolloo } \\
\text { Warabbeessa }\end{array}$ & 5 & Other parts & Bovine, Caprines & $\begin{array}{l}\text { Respiratory distress, } \\
\text { trebling, coma, death }\end{array}$ \\
\hline Datura stramonium & Asaangira & 6 & All parts & Bovines & $\begin{array}{c}\text { Pupils dilate, thirst, dry and } \\
\text { burning skin }\end{array}$ \\
\hline Guizotia scabra & Tuufoo Gurraacha & 4 & Leaf & Bovines & Neurologic signs \\
\hline Curly dock & Baala waraantee & 4 & Other parts & Caprines & restlessness \\
\hline Amaranthus Spp & Raafuu & 9 & Leaf & Bovine, Ovine, & Amaranthus spp \\
\hline Plantago lanceolata & Qorxobbii & 7 & Leaf and stem & Bovine, Ovine & Bloating, diarrhea \\
\hline Trifolium hybridium & Siddisa & 25 & Leaf and stem & Bovine, Ovine & Bloating, diarrhea \\
\hline Prunus Africana & Hoomii & 4 & Leaf & Caprine, Bovine, Ovine & $\begin{array}{c}\text { Diarrhea, loss of appetite, } \\
\text { depression }\end{array}$ \\
\hline $\begin{array}{c}\text { Snowdina } \\
\text { polystarchina }\end{array}$ & Muujjaa & 15 & Leaf and stem & Bovine, Ovine, & Snowdina polystarchina \\
\hline Ranunculus sardous & Balalaga & 4 & Leaf and stem & Ovine's & $\begin{array}{l}\text { Oral and gastro intestinal } \\
\text { irritation }\end{array}$ \\
\hline Urtica doca & Gurgubbee & 9 & Leaf and stem & All animals & Skin burn \\
\hline Solanium carolinense & Hiddii & 2 & Other parts & Ovine, Bovine & $\begin{array}{c}\text { Diarrhea, loss of appetite, } \\
\text { depression }\end{array}$ \\
\hline Solanium Spp & Dinnicha & 4 & Other parts & Bovines & $\begin{array}{l}\text { Depression, salivation, } \\
\text { diarrhea }\end{array}$ \\
\hline $\begin{array}{l}\text { Lycopersicon } \\
\text { enculentum }\end{array}$ & Timaatima & 3 & Leaf and stem & Bovines & $\begin{array}{l}\text { Salivation, abdominal pain, } \\
\text { anorexia }\end{array}$ \\
\hline Malus sylvestris & Appilii & 1 & Leaf & Ovine's & \\
\hline Ricinus cumunus & Qobboo & 5 & All parts & Bovine, ovine & $\begin{array}{c}\text { Weakness, salivation } \\
\text { diarrhea, mydriasis, teeth } \\
\text { grinding }\end{array}$ \\
\hline Giradinia bollosa & Doobbii & 3 & Leaf and stem & All animals & Restlessness and irritation \\
\hline Acacia abynica & Kichuu laaftoo & 1 & Leaf & Bovines, Caprines & Bloating \\
\hline Sesbaniya exaltata & Sasbaaniyaa & 2 & Other parts & All animals & $\begin{array}{l}\text { Walking stiffly, diarrhea, } \\
\text { hemorrhaging }\end{array}$ \\
\hline
\end{tabular}




\begin{tabular}{|c|c|c|c|c|c|}
\hline Pteriddium aquilinum & Tirimmii & 4 & All parts & Bovine, equine & $\begin{array}{c}\text { In coordination, nervousness, } \\
\text { anemia }\end{array}$ \\
\hline Lantana camara & Akaayii simbiraa & 1 & All parts & Bovine & Photosensitization \\
\hline Persea Americana & Avokaadoo & 1 & Leaf & Caprine, ovine, Bovines & Mastitis, heart failure \\
\hline Hyparrhenia rufa & Saarmallee & 1 & Leaf and stem & Bovines & $\begin{array}{c}\text { Sub mandibular swelling, } \\
\text { weight loss }\end{array}$ \\
\hline Phytolacae dodecandra & Handoodee & 1 & Other parts & All animals & $\begin{array}{c}\text { Diarrhea, salivation, } \\
\text { depression }\end{array}$ \\
\hline Albatia schimperiana & Mukarbaa & 1 & Leaf & Caprines, ovines & $\begin{array}{c}\text { Abdominal pain, depression, } \\
\text { reduced appetite }\end{array}$ \\
\hline Solanium nigrum & Hawwitii sarootaa & 1 & Bovines, ovine's & $\begin{array}{c}\text { Constipation diarrhea, } \\
\text { salivation }\end{array}$ \\
\hline Medico sativa & Alfalfaa & 1 & Leaf and stem & $\begin{array}{c}\text { Bovines, ovine's, } \\
\text { equine }\end{array}$ & Bloating, diarrhea \\
\hline Conium maculatum & Wancabbii & 1 & All parts & Bovine, ovine, caprine & $\begin{array}{c}\text { Diarrhea, ataxia, salivation, } \\
\text { coma }\end{array}$ \\
\hline
\end{tabular}

\section{Discussion}

The current study showed that photo poisoning is the cause of ill health in livestock in the study area. Out of 130 interviewed individuals $(120$ of livestock owners and 10 animal health professionals), $85 \%$ of livestock owners and $100 \%$ animal health professionals informed that plant poisoning is posing significant livestock health problems in the area. According to information collected from the respondents, the condition is provoked by scarcity of forage supply due to different reasons such as agricultural expansion, drought, soil erosion, over grazing which force animals to browse perennial shrubs and bushes while most of these perennial plants have been known to contain toxic secondary metabolites and the result of this study was in agreement with the study findings reported in the Sokoto state, Nigeria [12,13] by sharing similar risk factors and also with research finding reported from in the North Central America [14].

In this study, 33 plants having toxic effect to livestock were identified. Of these, Trifolium hybridium (25), snowdina polystarchia (15), Plantago Laceolata (12), Urtica doca solanium(9), guizotia scabra(7) were the most frequently complained toxic plants. The differences might be due to various plants growing in different geographical areas that have different geographic and climatic factors. These factors also contribute to the variations in the chemical composition of different poisonous plants in different areas. In the same manner, the variation might also be due to differences in level of information about these plants in the community from which the information was collected [15]. According to data obtained from different published literatures, most of the currently identified poisonous plants have worldwide importance. For instance, Medico sativa is phototoxic plant containing photo estrogen which is responsible for the reproductive disorders in addition to bloating and other effects to poisoned animals in the study area. A similar harmful effect of this poisonous plant was also reported in Colombia [16,17].
The current study revealed that, an increase in the degree of livestock poisoning by these toxic plants is corrected with factors such as drought which was agreed with the finding reported in USA (NCR, 1972)

[18]. Similarly, the importance of Trifolium Spp, Ricinus cumunus and acacia Spp as causes of livestock poisoning have been published in the different literature (Munro, 2009). Pteridium aquilinium (Bracken fern) is also widely distributed in many parts of the world. In Ethiopia, its existence and importance as cause of enzootic hematuria has been previously shown in different regions [19] and it has also been reported elsewhere [20].

The results of current study also indicated that livestock production in the study area was mostly extensive type with a very low population of animals kept under intensive production systems. Land used for extensive grazing cattle contain complex mixes of native and invasive plants which may increase the risk of exposure to toxic plants, many of which have not been identified and characterized to avoid livestock exposure and this finding was in agreement with study result reported by in Brazil [21].

\section{Conclusion and Recommendations}

In general, based on the results of present study, it is possible to conclude that, plant poisoning was one of the livestock health problems in the study area. Depending on the result of present study, the following recommendations were forwarded:

a. Preventing livestock from grazing the pasture infested by poisonous plants.

b. During drought season providing livestock with sufficient feeds to avoid the exposure to plant poisoning while searching for feeds.

c. Hay and other feed stuff should be carefully inspected for contamination with potentially toxic weeds before feeding. 
d. Livestock owners should be advised to remove the toxic plants from the pasture land.

e. Awareness creation should be made among the community on the practice of intensive livestock management system to minimize exposure of plant poisoning on the field.

f. During early spring season, livestock owners should give due attention to the area where their livestock graze because many poisonous plants grow and appear on the grazing field in this season.

g. It is recommended that detailed investigation should be performed to know the epidemiology of the poisonings caused by plants.

\section{References}

1. Radwan M (1974) Natural resistance of plants to mammals. In wild life and forest management in the Pacific North west, Symposium proceedinfs, Oregon state University, Corvalis, Oregion p. 85-94

2. Mugera G (1970) Phytolaccadode Candral Herit toxicity in livestock in Kenya. Bull Epizoot dis Afr, 18: 41-43.

3. Guluma K, Debela A, Morka A (2017) Ethnoknowledge of plants used in veterinary practices in Midakegn district, west showa of Oromia region, Ethiopia. Journal of Medicinal Plants Studies 5(5): 282-288.

4. Botha C, Penrith M (2009) potential plant poisonings in dogs and cats in Southern Africa 80(2): 63-74.

5. Gilbert S (2012) A small dose of toxicology, $2^{\text {nd }}$ Edition 124: 595-603.

6. Slaughter R, Michael D, Beasley G, Lambie B, Wilkins G (2012) poisonous plants in New Zealand:a review of those that are most commonly enquired about to the National Poisons Centre. Med J 125: 87-118.

7. Tamilselvan N, Thirumalai T, Shyamala P, David E (2014) A review on some plants and their medicinal values 3(2): 85-89.

8. Botha J, Penrith M (2008) Poisonous plants of veterinary and human importance in Southern Africa 119(3): 549-558.

ISSN: 2574-1241

DOI: 10.26717/BJSTR.2019.23.003897

Debela Abdeta. Biomed J Sci \& Tech Res

(C) This work is licensed under Creative Commons Attribution 4.0 License

Submission Link: https://biomedres.us/submit-manuscript.php
9. Filigezi M, Puschner B (2005) Determination of oleandrin in tissues and biological fluid by liquid chromatography electro spray tandem mass spectrometry. J Agric food chem 53(11): 4322-4325.

10. Kaufmann R (1986) livestock system research in Nigeria's sub humid zone. Publication pp. 186-283.

11. Filigezi M, Puschner B (2005) Determination of oleandrin in tissues and biological fluid by liquid chromatography electro spray tandem mass spectrometry. J Agric food chem 53(11): 4322-4325.

12. Ebbo A, Agaie B, Adamu U, Daneji A Garba H (2003) Retrospective analysis of cases presented to the veterinary teaching hospital, Sokoto, Nigeria veterinary journal 23: 3-5.

13. Onyeyili p, Chibuzo G, Brisaibe F, Egwu G (1996) accidental plant poisoning of sheep in acid zone of Nigeria and agriculture of the district.

14. Martison K, Lynn H, Mike M (2006) plants poisonous or harmful to horses p. 46-63.

15. Dereje A, Tariku J, Teshale S, Ashenafi F, Takele B (2014) Assessment of plant and chemical poisoning in livestock in Central Ethiopia. J Enviro Anal Toxicology 4: 215.

16. Seguin P, Zheng W Souleimanov A (2004) Alfalfa Phytoestrogen content, impact of plant maturity and herbage components. J of agronomy and crop science 190: 211-217

17. Munro D (2009): Canadian poisonous plants information system. $2^{\text {nd }}$ edition.

18. Galey F, Holstege D, Fisher E (1992) Toxicosis in dairy cattle exposed to poison hemlock (conium maculatum) in hay:isolation of conium alkaloids in plants, hay and urine. J Vet Diagn Invest 4(1): 60-64.

19. Radostits O, Gay C, Hinchliff K, constable P (2007) veterinary medicine, a text book of the disease of cattle, horses, sheep, pigs and goats 10 th edn. saunders, Elsevier, London pp. 1851-1895.

20. Redeleff R (1964) veterinary toxicology. London,Bailliere, Tindal \& Cox, USA.

21. Tokarnia C, Dobereiner J, Peixoto P (2002) Poisonous plants affecting livestock in Barazil. Toxicon 40(12): 1635-1660.

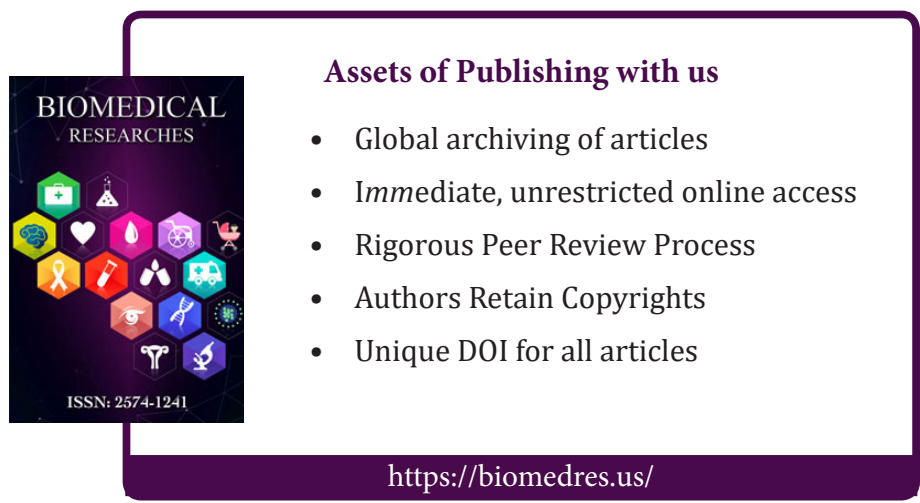

